\title{
African Bioconservatism and the Challenge of the Transhumanist Technoprogressism
}

\author{
Denis-Ghislain Mbessa \\ Department of Philosophy, Faculty of Letters and Social Sciences, The University of Douala, Douala, Cameroon \\ Email: mbessadeghis@gmail.com
}

How to cite this paper: Mbessa, D.-G. (2020). African Bioconservatism and the Challenge of the Transhumanist Technoprogressism. Open Journal of Philosophy, 10, 443-459.

https://doi.org/10.4236/ojpp.2020.104031

Received: June 22, 2020

Accepted: November 7, 2020

Published: November 10, 2020

Copyright (c) 2020 by author(s) and Scientific Research Publishing Inc. This work is licensed under the Creative Commons Attribution International License (CC BY 4.0).

http://creativecommons.org/licenses/by/4.0/

(c) (i) Open Access

\begin{abstract}
This reflection focuses on the interaction between technoscience in general and the Transhumanist movement in particular on the one hand and African culture today on the other hand. Traditional African culture can be considered as a bioconservative culture, what Tangwa calls eco-bio-communitarianism. However, the ideology underlying the Transhumanist revolution is Technoprogressism with a frantic taste for the artefactual over the natural and the promotion of artificial intelligence. In the face of the Transhumanist movement, can the African still remain bioconservative? In this paper, relying on Godfrey B. Tangwa's work on the African perspective of bioethics and Jerome Mbih Tosam's paper which analyses African environmental ethics in view of sustainable development, I would like to suggest a positive interaction between the African bioconservative or pro-life attitude and Western Technoprogressism in this era of Transhumanist revolution. Africans, while inevitably opening up to the world, to the Promethean spirit, must be able to preserve the traditional values which constitute the soul of their culture and which participate in the protection of the environment, the protection of life, the protection of human dignity at a time when the world is experiencing an ecological and health crisis under the effects of the omnivorous spirit of research that characterizes Western culture.
\end{abstract}

\section{Keywords}

Bioconservatism, Technoprogressism, Transhumanism, African

Environmental Ethics, Bioconservative Technoprogressism

\section{Introduction}

When we talk about Africa, we very often think of a continent full of "traditions". As Damase Djongongele Otshudi (2011: p. 171) points out, "tradition is probably the most common word when it comes to talk about African society". 
Now, the essence of tradition lies in the dual need for conservation and transmission. What is preserved and transmitted over time is not only a set of values, ways of being, customs, but also and above all a spirit, a vision of the world, a way of conceiving existence that ethnologists call "Weltanschauung". Consequently, in the era of the techno-scientific revolution in general and the Transhumanist revolution in particular, we are observing changes in attitudes, ways of being and thinking, but also and above all a replacement of values.

Thus, the legendary Bioconservatism of traditional African societies is gradually being replaced by the successful Technoprogressism of modern societies. Abortion and euthanasia are gradually replacing the pro-life attitude, the unbridled taste for the artefactual, Artificial Intelligence and all its gadgets are gradually replacing the taste for the natural, and individualism is gradually replacing communitarianism as Westernisation progresses under the guise of globalisation. Fortunately, there is a resilient presence of surviving traditions in African culture which are sometimes seen as useful in providing solutions to global problems caused by Western technology and sometimes as obstacles that must be overcome in order to emerge by taking hold of the European spirit. This reflection thus focuses on the interaction between the Transhumanist movement on the one hand and African culture today on the other. In the face of the Transhumanist movement, can the African still remain bioconservative? What attitude should be adopted in Africa in this context of the Transhumanist revolution?

Some scholars like Marcien Towa and Elungu Pene Elungu have argued that the only way for African development is through the rejection of her traditions and the adoption of Western science and technology. Such a perspective is rooted on the conviction that modern science and technology have been the vectors of the development of the Western world. As such, if African society wants to reach the level of development of Western societies, science and technology must occupy the same place and play the same role in Africa. Against such a theory, in this paper, I argue that there can be a positive interaction between the African bioconservative culture and the Western Technoprogressist culture in this era of the Transhumanist revolution. Godfrey B. Tangwa has developed an African perspective of Bioethics in order to insist on the fact that though Western technology and Biotechnology have improved living conditions for humanity, they have also brought about many problems which cannot be solved by technology and whose solutions can be found in the African bioconservative culture. The objective of this research is therefore to advocate the preservation of the African cultural values which can contribute to the preservation of life in the face of the risk of acculturation brought about by Western science and technology and the technoprogressist ideology on which the Transhumanist movement relies.

After presenting the need to connect Africa to the Transhumanist movement, I will demonstrate the need to preserve the African bio-conservative/pro-life attitude in order to reconcile Bioconservatism and Technoprogressism in the quest for the emergence of this continent. 


\section{The Transhumanist Revolution: An Invitation for Africa}

By "Transhumanist revolution" I mean a set of changes in the world of technoscience brought about by the convergence of NBICs. Transhumanism itself is a philosophical and scientific movement that intends to substantially enhance the physical, intellectual or mental capacities of the human being through a systematic process of "repair", "transformation" and "enhancement" of human nature with a view to the "improvement" of living conditions on earth and the coming of a posthumanity that escapes all forms of limitations such as suffering, pain, illness, aging and even death. The expression "Transhumanist revolution" is from Luc Ferry who, through his book, considers that some perspectives opened by technoscientific innovations are exciting, others frightening. He then seeks to make them understood, and to rehabilitate the philosophical ideal of regulation, a notion that is now vital, both in medicine and in economics, by showing how technomedicine is going to change our lives (Ferry, 2016).

\subsection{The Spirit of Transhumanism: A Spirit of Omnivorous Discovery and Domination}

It would have been desirable for technology, in accompanying medicine and man's daily life, to refrain from creating ethical and environmental problems and, above all, to refrain from undermining human dignity and the sacredness of life. Unfortunately, technology, or rather Transhumanism, does not limit itself in maintaining human health and improving living conditions. It goes further by substantially modifying his nature and advocating an excessive Technoprogressism to dominate nature and life. The driving force of science and technology and of Transhumanism is a spirit of discovery, exploitation, transformation, domination and conquest. In order to be powerful in the manner of Europe, Marcien Towa (1971: p. 40) invites Africans to develop this same spirit in the manner of the Western world. Towa thus recommends that Africans should have a thorough knowledge of Western culture in order to discover this spirit and make it their own. According to him, taking hold of the "secret" of the Western world must therefore consist in knowing Western civilization more profoundly, identifying the source of its power and introducing it into our own culture. But this introduction, as he says, should not be conceived as a simple addition that would leave the old cultural elements intact, nor even as a peaceful graft that should smoothly bring about the desired transformations: it implies that indigenous culture be revolutionized from top to bottom, it implies a break with that culture, with our past, that is to say, with ourselves.

It is then that the Cameroonian philosopher uses the figure of Cheikh Hamidou Kane's Grande Royale who, in my opinion, incarnates the revolutionary spirit, the new scientific spirit, to speak like Gaston Bachelard, which must get rid of epistemological obstacles represented by her Diallobé community deep-rooted in its tradition. Grande Royale recommends the people of Diallobé to send their children to school even though that school will kill in them their traditional values and their identity because this Western school will open the doors to science and 
technology and will develop in these children the Promethean spirit (Hamidou Kane, 1961: pp. 61-62).

In the same logic Towa recommends that Africans should seize this spirit which he considers to be the property of the Western world. The Promethean spirit is also perceived by Tangwa (2010: p. 42) as a spirit of domination and omnivorous discovery. Among the catalysts of change in the Western world, he sees the Industrial Revolution of the $18^{\text {th }}$ and $19^{\text {th }}$ centuries as a major one. He considers that the Industrial Revolution drew its impetus from Francis Bacon's slogan that "knowledge is power" convertible into commercial value, from the idea that all knowledge is unqualifiedly good, from the belief that nature is, in principle at least, completely knowable and controllable, and from perception of the universe as something which ought to be explored, subdued, dominated and exploited. Hence, the cumulative effect of these very important achievements was to infuse in Western culture a spirit of omnivorous discovery, an automatic impulse towards unifying, patenting, monopolizing and commercializing such discoveries and a penchant for spreading and promoting its ideas, vision, convictions and practices under the guise of universal imperatives of rationality and morality which ought to be binding on all and sundry.

\subsection{The Necessity for Africa to Respond to the Transhumanist Invitation}

Even if I do not agree with the idea of europeanizing the spirit of invention and creativity, because this spirit is scattered in the world in tiny morsels, just like wisdom, what is true is that Africa's connection to the Transhumanist revolution is justified by the fact that she is lagging behind in every respect and by the fact that Transhumanism is accompanied by a power that will always place this continent in a situation of marginalisation. Being connected to the Transhumanist movement does not imply that Transhumanism must be embraced in all directions because the commercialization of the technoscience, in which Transhumanism engages humanity, involves the commercialization of human organs, genes, viruses, diseases, spy objects, which endangers the future of humankind and, by extension, the dignity of the human being. The natural or biological man is bound to become a threatened species, an endangered species if we allow "Perfectist Transhumanism" to flourish.

By "Perfectist Transhumanism" I mean the version of Transhumanism that postulates the idea of the perfect man, the cyborg, completely artificial. It is rather a question of knowing how to lucidly take advantage of the Transhumanist revolution, especially with regard to technomedicine, which endows humanity with new powers. We only have to read the first chapter of Njoh-Mouelle's (2018: pp. 11-26) second book on Transhumanism entitled "Benefits of some research results in NBIC" where he underlines the new powers of man over man thanks to technomedicine precisely: blind people can regain their sight, deaf persons can regain their hearing, diabetics can protect themselves from unpleasant surprises, quadriplegics can start walking again, Parkinsonians can stop shaking, 
Alzheimer's patients can regain their memory.

As such, Transhumanism, as long as it is limited to the improvement of life and its protection, is a humanism that is in line with the African bioconservative culture. In this respect, it should be promoted within the African continent. There is therefore a line of demarcation between the humanism that is always present in technomedicine and Transhumanism in its pejorative or perfectist version, especially that which consists in trampling on human dignity under the pretext of transforming, enhancing and perfecting man. Njoh-Mouelle (2018) writes:

Patching up by technology, when it comes to maintaining man in a good health and capable of enjoying autonomy to continue living in dignity, has nothing to do with transformation projects of human nature leading to the emergence of new values inspired by new and different purposes assigned to a new being called "Cyborg" or "Posthuman". (2018: 26)

Africans can develop-and not necessarily adopt-this Promethean posture in order to appropriate the secrets of technomedicine that leads to meliorative Transhumanism; but, is such a quest compatible with the "pro-life" or "bioconservative" attitude?

\section{The Relevance of African Bioconservatism}

Marcien Towa advocates a radical break with our traditions. Emphasizing the place that technology and science must occupy in the development process in Africa, he develops a theory of development solely through technoscience. This theory, Otshudi (2011: p. 181) tells us, is grounded on a simple premise: modern science has been one of the driving forces behind the development of Western society. It therefore follows that if African society is to reach the stage of development achieved by Western society today, modern science must be able to occupy a similar place and play the same role in Africa.

However, it is my conviction that a people's development cannot be achieved in conformity with the exclusive model of another, each people having its own needs, the satisfaction of which is part of what is called development. Thus, Africa's development cannot do without its own culture, a culture that is bioconservative in several respects. Africa's bio-conservative attitude is moreover justified in view of the ecological and health crisis into which the spirit of omnivorous discovery and the Technoprogressism underlying the techno-scientific revolution in general is increasingly plunging us. But before demonstrating the benefits of the African bio-conservative attitude, it is necessary to describe it a little.

\subsection{The African Bio-Friendship Attitude}

When we talk about culture, we envisage a set of ways of being, thinking and interacting that are specific to a people. What should already be stressed is that each society's perception of nature profoundly influences the way it treats nature, and that the way a society relates to nature can either improve or degrade 
the health of the environment. If we perceive nature as something of which we (humans) are an integral part, and as equal partners, with whom we share a common habitat, then we can treat it with respect (Gratani et al., 2016: p. 2). On the contrary, if we consider nature as something inferior to us, we can treat it with contempt. The anthropocentric worldview that considers nature as inferior to humans, who are therefore mandated to dominate and exploit it, is the underlying modern Western philosophical view of nature, and has undoubtedly contributed to the unsustainable-i.e. abusive-exploitation of the natural environment.

Prior to the colonial encounter, Africa had a different worldview and attitude to nature from that of Western peoples. The traditional African attitude towards nature was to live and let live, to be and to let be, to protect and care for, which favoured the sustainable management of natural resources. Increasingly, the international community is becoming aware that humans are called upon to broaden their moral vision to include land, water, plants, animals, or, collectively, the earth. Yet, environmental consciousness has always been an integral and essential part of traditional African ethics. This can be understood in the holistic African moral perspective that integrates the anthropological, ecological and spiritual components of reality. According to Tangwa (2010),

The traditional African system, to the extent that it has survived Western colonization, domination and exploitation, or to the extent that it can still be recalled and salvaged from the receding African past, is characterized, inter alia, by its epistemological humility and procedural caution, eco-biocommunitarianism, egalitarianism, leveling tendency and an obsession with moral uprightness. (2010: 75)

The moral righteousness inculcated in the young African from an early age was based on the sacredness of taboos. These taboos were intended to ensure that goods that were by no means luxuries but were essential for mere survival, and which had moreover been abundantly provided by God in nature, were available and accessible to all. A taboo against the manipulation and commercialization of things such as genes and gametes would have been seen in the same light in such a socio-cultural context. For example, there were strict taboos on eating or killing certain insects, reptiles, birds and animals (Tangwa, 1996: p. 189), which ensured the survival of fauna and flora. It was also forbidden to kill pregnant animals and if these animals were killed by mistake, purification rituals had to be carried out. There were taboos against the killing of domestic animals bred primarily for the purpose of companionship and assistance to humans, such as dogs, cats, horses and donkeys.

Thus, as Tangwa (2010: p. 57) points out, the pre-colonial traditional African metaphysical attitude can be described as "eco-bio-communitarian", implying recognition and acceptance of interdependence and peaceful coexistence between earth, plants, animals and humans, by contrast with the Western attitude which could be described as anthropocentric and individualistic. From the Afri- 
can perspective, human beings tend to be more humble and cautious, more distrustful and uncertain of human knowledge and capabilities, more accommodating and respectful of other people, plants, animals, inanimate things, as well as various invisible/tangible forces, more timid, in short, more willing to adopt an attitude that protects life and lets live. In this worldview, says Tangwa, The distinction between plants, animals and inanimate things, between the sacred and the profane, matter and spirit, the communal and the individual, is a slim and plastically flexible one. For instance, the belief that humans can transform into animals, plants, such as trees, or forces, such as the wind, is very rampant within this system and has very significant implications for the way and manner nature as a whole and in its various specific manifestations is approached.

\subsection{African Bioconservatism and Environmental Ethics}

The African bio-friendly attitude is at the basis of traditional African environmental ethics. Here, human beings are mere co-occupants of nature with other species without any heavenly mandate to dominate, subdue and exploit nature. This attitude towards nature is diametrically opposed to the mechanistic and anthropocentric vision initiated by Francis Bacon and René Descartes, which sees humans as privileged members of the ecological community with the moral authority to subdue, control and monopolize the rest of nature, a vision that is based on the biblical text of creation that commands humans to subdue the earth.

Unfortunately, through the phenomenon of globalisation, the industrialised Western world is "globalising not only its technology but its socio-cultural values as well, which, taken together, give some cultures, such as African culture, little or no chance of surviving globalization" (Tangwa, 2010: pp. 46-47). We then gradually notice a loss of values in traditional societies, with the culture of freedom proudly replacing that of taboo and the culture of children's rights proudly replacing that of parental authority even in our villages. Mbih Tosam (2019: p. 186) rightly points out that the "traditional metaphysico-religious beliefs and customs which encouraged environmental conservation are fading away and are gradually being supplanted by Western eco-philosophical beliefs and practices."

Yet, considering the ecological and health crisis the world is experiencing today, traditional African environmental ethics can be salutary.

Since the world has become a family, at least that is what the concept of the "global village" suggests, solutions must be found to assist our planet in the process of healing its wounds. Among these solutions is the pro-life or bio-conservative attitude recognized in traditional African societies. Mounkaïala Abdo Laouali Serki (2006: p. 79) then considers, with great optimism, that African humanism is a sort of lifeline for the world in crisis. According to him, while the power of Western technoscience on contemporary societies is increasing and neo-liberal globalisation is subjecting them to unprecedented competition, a profound crisis of values is affecting our societies. But against all expectations, a glimmer of hope seems to be emerging from the humanism inherent in African 
culture, as if to tell us that, in difficult times, it can point the way out of the crisis.

From the above analysis, it goes without saying that African Bioconservatism and the African environmental ethics that is rooted in it can help mitigate the devastating effects of modern science and technology on the environment, on human dignity and on life in Africa and worldwide. Consequently, as Mbih Tosam (2019: p. 172) points out, African environmental ethics can contribute to sustainable development because it extends the moral community beyond anthropocentric concerns by including animals, plants, unborn children and the supernatural in the moral universe. It is therefore clear that indigenous African societies have used several traditions, customs, rituals, beliefs and practices to make their environment physically and spiritually sustainable.

\subsection{African Bioconservatism and World Sustainability}

Following Mbih's argumentation on the link that exists between African environmental ethics and sustainable development, it is clear that African Bioconservatism is an attitude that can foster sustainability in a world which is suffering from environmental crisis. As noted above, there were taboos, values and norms that prescribed correct behaviour towards nature. But as a result of the colonial encounter, Africans were forced to abandon some of these indigenous environmental values and sustainable practices for an anthropocentric approach. From this perspective where man has moral responsibility only towards man, development meant total disregard for traditional African holistic values and customs. This disregard, coupled with the weakness or absence of an institutional framework for environmental protection and corruption in the management of natural resources, has led to an abusive exploitation of the natural environment in Africa. Mbih Tosam (2019: p. 174) then argues that "it is time for African governments to start appraising and encourage the re-institution of traditional conservationist values and practices to help extenuate the adverse effects of climate change in Africa and promote sustainable development on the continent".

Thus, the idea that nature must be understood, mastered, controlled and profitably exploited by human beings, which is the greatest driving force of Western culture, if not moderated in some way, may sooner or later turn this concern into alarm. Such ideas are quite foreign to some cultures, such as the African culture and way of life, which are in admiration of nature, towards which, moreover, there is an attitude of great respect, prudence and peaceful coexistence. It can be said that the general attitude of Africans towards nature is bio-protective. "Such an attitude, Tangwa (2010: p. 44) tells us, if lent and borrowed in the process of globalization, could help in tempering and balancing the Western outlook" towards the environment". It is precisely in order to moderate and balance the Western perspective of excessive exploitation of nature that the vision of a development compatible with the concern for nature conservationsustainable development-has been developed. 
Indeed, the idea of sustainable development was born out of the desire to achieve economic growth for all, rich and poor, without harming the health of nature-environment. There is therefore an intrinsic relationship between environmental ethics and sustainable development and "Indigenous African environmental beliefs and values can promote environmental conservation in diverse ways" (Mbih Tosam, 2019: p. 186). The idea of sustainable development reinforces the world view that we are obliged to take future generations into account in our policies, in our production and consumption of material goods, in our very interaction with the natural world and in our daily decisions.

In any case, it is clear that nature conservation in the African ecological perspective aims at both human and environmental survival. The need to respect nature in the context of traditional African societies is justified by the fact that although humans have a moral responsibility, they do not consider themselves as privileged beings with a celestial mandate to conquer, control and exploit the rest of nature. Human well-being is the goal, end and purpose of morality. Because human beings live in a harmoniously integrated cosmos, where they depend on other beings for survival, it therefore follows that they must value other members of the universe equally. In this moral universe, only human beings have moral obligations to the environment. Mbih Tosam (2019: p. 186) then concludes that African environmental ethics teaches us that human beings are not a privileged species with special rights over the rest of nature, but that they are only a small (and even the most destructive) part of nature.

In the light of all the foregoing, we can say that the attitude of traditional African man is, by nature, respectful of the environment, protective of life, conservative of everything that contributes to the preservation of being. This concern for the preservation of life is reflected in the need to live in community and to keep the flame of life burning within the members of the community through celebrations of all kinds and through the transmission of values from the ascendants to the descendants within the family, the cell of conservation of life and values par excellence. This communitarian spirit is increasingly being put to the test with the rise of individualism that the so-called modern culture brings with it.

Unlike the traditional man, the modern man has become a solitary being who prefers the company of devices and gadgets to that of his parents, brothers and sisters. What is virtual now prevails over what is real and what is artificial over what is natural. One can already live alone in the midst of many machines and gadgets but the life that flows in the presence of the other self can never be replaced by technology. According to this logic, someone's life as well as his death, his joys as well as his sufferings can leave us indifferent as long as we have our telephones, computers and other machines at our disposal. Modern man has become an electronic being who is gradually losing the natural taste for life and the free tenderness provided by human warmness (Mbessa, 2018: p. 87).

Africans must therefore avoid losing, no matter what, their pro-life attitude, 
their bio-conservative culture and their community spirit, in the name of the quest for progress which is at the same time alienating and destructive. They should rather find ways and means to preserve this attitude, which, as I have just demonstrated, is a reserve of eco-humanism in a world that is undergoing an ecological and heath crisis. Technology can really be profitable to them if only it is used to this end.

\section{The Way out of Acculturation: Bioconservative Technoprogressism}

If the Transhumanist revolution is a challenge for the African bioconservative culture as I have argued above, it is therefore necessary to reflect on means to avoid another form of apartheid in Africa. It is evident that African development cannot avoid the path of Western technology but in my opinion, it must not at the same time avoid the path of African traditions. I therefore stand for a positive interaction between African culture and Western technology in this era of the Transhumanist revolution that may maintain Africa in a permanent situation of marginalisation in the global world bio-business. Before presenting the way that can lead Africa out of acculturation, I wish to describe what I mean by "Bioconservative Technoprogressism".

\subsection{What Is Bioconservative Technoprogressism?}

The idea of "Bioconservative Technoprogressism" that I am developing here is already contained or implied in the idea of sustainable development. Nevertheless, what I want to stress is the need to preserve, from past to present and from present to future, in Africa and in the world, the pro-life attitude which is strongly threatened by Transhumanist perspectives. Indeed, in the name of progress, what is artefactual is increasingly taking precedence over what is natural and the biological man, genetically modified and repaired here and there and technologically enhanced especially there-in the Western world-, is fast becoming an endangered species, a species to be protected against the posthuman, the cyborg. It is therefore in the field of the Extinctionist perspectives of Transhumanism that the expression "Bioconservative Technoprogressism" takes on its full meaning.

In any case, my standpoint is that it is necessary to conserve life, to save natural man in the face of the technological advances that arise from the convergence of NBICs. In order to do this, I believe that extremist positions which consist either in totally rejecting African tradition in order to enter passionately into scientific modernity on the one hand, or in claiming African authenticity, in a nostalgic and inoperative Afrocentrism because it is incapable of leading Africa to progress on the other hand, must be avoided. For me, there is a third way, a middle way between the excessive quest for progress solely through technology on the one hand and the concern to preserve life in all its manifestations without, however, remaining underdeveloped on the other. This path is precisely "Bioconservative Technoprogressism", which seeks to reconcile bioconservative tra- 
dition and technoprogressive modernity. Before setting out the guidelines for this path, let me first present the dangers of Technoprogressism.

\subsection{The Dangers of Technoprogressism and the Challenge of the Transhumanist Revolution for Africa}

The omnivorous spirit of research, as Tangwa qualifies it, has (bio) destructive consequences that extend to both the environment and human nature. As mentioned above, my concern is to stress the need to preserve natural life in the battle for technological progress. The techno-scientific spirit endows man with powers that make the boundary between what is impossible and what is possible more crossable than ever before. Yet, by going beyond both the ecological and the egological footprint, technology ends up stripping the universe of its biological footprint and humans of their spiritual fabric. According to Mounkaïala Abdo Laouali Serki (2006: p. 75), the more technoscience progresses the greater the risk of a global catastrophe. In other words, science, in which conscience breathes less and less because of a frantic race towards progress, would end up subjugating man by stripping him of his spiritual component.

Today, in Africa as in the rest of the world, it is unthinkable to live without technology. The high-tech culture shapes humans everyday life to such an extent that the idea of the natural man-not strictly in the Rousseauist sense of a being without reason, but in the sense of an intelligent being without technology-is probably no longer conceivable. The normal man is the modern man equipped with machines and gadgets of all kinds; but also more and more electronic chips (instead of neurons), batteries (instead of lungs or hearts) and organs shaped, i.e. repaired, enhanced and transformed according to the whims of cosmetic surgery. Hannah Arendt (1972: p. 340) writes that modern science has so radically changed and reconstructed the world we live in that it could be objected that the layman and the humanist, by continuing to trust their common sense and to communicate in everyday language, are no longer in touch with reality. It can therefore be said that Western technology, especially biotechnology, whose success, power and influence cannot be disputed, has created many problems that cannot be solved by technology itself. The solution to some of these problems could possibly come from the direction of cultures that are generally described as technologically backward or underdeveloped, because these problems are not in themselves technological problems, even if they arise from or are related to technology (Tangwa, 2010: pp. 74-75).

Among the problems that emanate from Western technology is the artificialisation of life through its electronicisation. This electronicisation of life to which modern man is increasingly exposed is at the same time a denaturation of life, a disintegration of the family and a disruption of the social network through a hypermediatisation of Western culture (Mbessa, 2018: pp. 87-88).

In my opinion, therefore, the race towards progress must not be accompanied by the loss of the natural taste for life. Technology must be subordinated to life 
and not the other way around. The community spirit which animates social media in the management of information and problems of various kinds must not remain at the virtual level. For example, a beautiful natural smile offered to the other person on the street is much more precious than an emoticon sent through social media. For Tangwa (2010: p. 47), it should not be taken for granted that the Western ideology of possessive individualism should be an integral part of technology. Unfortunately possessive individualism is an ideology that accompanies Western technology.

In reality, Transhumanism is not concerned with the intransience of man's natural nature. The project here is all about taking man from the natural to the artefactual stage while claiming to make him more human, more perfect in the figure of the posthuman or the cyborg. Njoh-Mouelle (2017: p. 80) underlines this Transhumanist project of annihilating human nature when he affirms that "the central idea that supports the Transhumanist view of things is that human nature has nothing intangible". With Transhumanism, it is all about revealing human potentials or virtualities which are not yet actualized. The Transhumanist project of perfecting human nature has nothing to do with the idea of its perfectibility as Rousseau presented it but it aims at revealing what would not be part of the potentialities or the virtualities inherent in human nature and called to be developed by culture, such as the reasoning faculty, the faculty of speech or any natural talent, but of additions more or less incompatible with the values of humanism. Such additions induce profound changes in human nature thanks to science and high technology.

There is therefore, in the Transhumanist project, an explicit disregard for the sacredness of life and human dignity. If there is nothing sacred about human nature, then it can be moulded at will by distorting it, by artificializing it through technology. According to Buju (2009: p. 288), the Western technological perspective does not contribute to making the world more humane; instead of promoting life, it has promoted death. He argues that only when the technological world listens to the symbolic language of nature will it be literate again and able to promote life instead of death. To make the world more humane is therefore to respect life and all that it nurtures: nature-environment, living beings, human nature, and this is only possible if we respect other cultures, especially those that perceive humans and nature as equal and interdependent members of the community and not in opposition to each other.

Transhumanism advocates a man-machine hybridization that can, through the uploading of consciousness into the machine, enhance the physical, intellectual or mental capacities of the human being in the figure of the cyborg. Man is thus called to become a machine, an electronic, mechanical being, a thing. Transhumanism inaugurates the passage from biological man to "technological man". The expression "the technological man" was coined by Victor Ferkiss (1972: pp. 234-235), who wishes to remind humanity of the need to preserve the natural character of the human species. He considers that at an even more elementary level, man must maintain the distinction between himself and the ma- 
chines of his invention. Man must remain superior to material technologies, otherwise they risk enclosing him in a protective but indestructible shell, and the principles governing their organisation could very well force him into an existence that would differ little from that which characterises certain insect societies.

To live like insects is to live subjected to the mechanisms, better, to the mechanics of instinct. It is to lead a robotic existence, devoid of any sentimental taste, it is to obey the law that the machine will dictate to a humanity that has disappeared under the influence of technological progress. The "technological man" will only be a machine supposedly humanized by a combinatorial, programmed, automated and artificial intelligence, what Ferkiss (1972: p. 245) calls the "human machine". He considers that before abandoning man for a human machine or anything else, we should learn what he is capable of doing in his present form, once he is freed from the scourges of hunger, fear and ignorance.

Instead of running the race of human transformation from the biological state to an artificial state, what is more urgent is to liberate man from war, hatred, suffering, without necessarily trampling with his dignity. For Hans Jonas (1991: p. 19), in his essence, in his substance, man, as he was created or as he came into existence, either by divine creative will or by the chance of evolution, does not need to be enhanced. Each individual can develop the deepest possibilities of his being; but he need not seek to transcend his nature because human nature must not be transcended. The future of humanity therefore lies in values that promote a certain humanism that takes care of human suffering, not to eradicate it in the name of the quest for immortality; but to alleviate it by leaving to life its natural taste imbued with limitations of every kind.

This future is under great threat from technology and the progressism that accompanies it. This technology needs what Bergson called a "supplement of soul" or a "conscience" to speak like Rabelais. But the conscience and soul supplement that humanity needs for the preservation of its future, that is to say the survival of the species of biological man, which is seriously threatened by Syllicon Valley researchers, are to be found in reserves of humanism, cultural fallow lands that can still be found, fortunately, in traditional African societies. Engelbert Mveng (1980: p. 152) argues that tomorrow's technology will be even richer, industry more adapted to the concrete problems of men, when Africa brings her original note to the concert of peoples who master technology and industry.

\subsection{Towards a Positive Interaction between Tradition and Technology}

Africa's "original note" is not only her traditional art, handicrafts or technology, which far from being an obstacle to our leap into the modern technological age, can bring us irreplaceable assets, as Mveng (1980: p. 156) argues; it is also, in many respects, as I have already demonstrated, part of the pro-life culture or the bio-frienshsip/bio-conservative attitude. Indeed, Kelbessa (2006: p. 25) shares this view when she argues that African attitudes towards the environment can offer ideas for reorienting the behaviour of technological societies towards a 
more sustainable path; and in general, global environmental problems can be better addressed through more intercultural and interdisciplinary approaches. This is why I advocate a complementary approach between Western technology and the African tradition.

Following the above argumentation it is obvious today that Africa needs modern technology and ideally, Africans should build a technology that suits with their socio-cultural background (Binet, 1983: p. 46). However, with globalisation which is nothing else than a process of westernisation that they cannot resist, Africans can only resort to Western technology for their development or at least graft it in their own culture. However, the grafting of technologicalWestern culture onto the old African trunk is a more complex operation than it seems (Ibid: 53-54). How then is it possible to reconcile the need for progress in traditional African societies with the concern to preserve traditional values that are losing ground in the continent?

To drive Africa out of underdevelopment, it is necessary that technoscience be rooted in African tradition in a harmonious combination because, as Otshudi (2011: p. 182) points out, if modern science can be the engine of development for Africa, it is tradition that will make this development authentic and appropriate. He develops a thesis that falls in line with my project of "bioconservative techno-progressism", namely, the partnership for development between modern science and African culture with its traditions, the terms of which he defines with this statement: "It is necessary both to cling to modern science and technology which have already proved efficient in development in the Western world and to cling to African traditions to moderate the traumatic effects of the impact of modern science and technology on African society today." (Otshudi, 2011: p. 183).

This thesis, which I highly approve and promote, is opposed to the radical revolutionary iconoclasm of Marcien Towa and the theory of "renouncing traditional Black Africa in view of a conversion, through science and technology, to the scientific spirit" advocated by Elungu Pene Elungu (1987: p. 180). For these two thinkers, Africa can only develop if she gets rid of her traditions. Elungu Pene Elungu (1987: p. 181) boldly invites Africans to "get rid of a folkloric originality that is opposed to the progress of science and the scientific spirit." As far as I am concerned, African development cannot ignore African traditions, which I have considered in this paper as a reserve of humanism through the bio-conservative values they promote.

Tradition is in fact a heritage, a cultural fallow land, a reserve of humanism that must not be broken at all costs in order to enter the dance of Transhumanism. With tradition, and it is not too much to recall this, it is possible to develop and systematize African traditional medicine, which often succeeds where modern science and technology fail. The fight against COVID-19 is still there to remind us of the benefits of indigenous pharmacopoeia. Africans must therefore not reject their achievements outright on the pretext that Western science or technology has imposed itself or that Transhumanism is in vogue. The example of China is 
quite illustrative of the need to reconcile openness to the world and the preservation of one's own culture. China has certainly undergone cultural revolutions, but Chinese identity remains visible through Chinese culture, including its technology, which it has managed to preserve. Jacques Binet (1983: p. 54) finally militates in favour of a cultural syncretism whose idea I embrace through "Bioconservative Technoprogressism" when he writes: "Going from modern culture to traditional culture and vice versa should be an easy and enriching process. All too often, Africans do not accept to attempt this integration, or do not think of doing so."

\subsection{Towards a Syncretistic Education in Africa}

In the light of all the above, I can say that openness to modern technology can be achieved by preserving not only African tradition but also, and above all, the freedom of Africans. Technology does not impose itself on them. They must be able to use it without alienating themselves. It is possible to put technology at the service of tradition in order to produce technical knowledge relating to botany, for example, and this can be done by digitalizing the knowledge found in the traditional milieu. Technology can also serve tradition through the development of applications that will make it possible to promote it: applications on the learning, teaching and extension of local languages with a view to their conservation, applications on the management of our natural resources with a view to improving our agricultural techniques, applications on the development and promotion of endogenous knowledge, all this with a view to the development of Africa rooted in its ancestral cultures and traditions.

Instead of taking the path of radical revolutionary iconoclasm or ethnological conversion, I recommend the path of a syncretistic education enabling young Africans to live in a modern world while preserving their identity and freedom, the path of Western technology serving tradition, the path of Transhumanism integrating prolifeness or the path of modernity respecting and collaborating with tradition. Jacques Binet (1983) presents these two paths when he writes:

The first path is that of a cultural revolution, which is traumatic, dangerous, costly and it can lead to chaos. The other path should allow common man to understand that today's progress takes up the line of thought that led the ancestors to move from hunting to agriculture, from stone tools to metallurgy. We can then hope that men will be free enough in their conscience to accept, refuse, modify according to their needs what the scientific world proposes. (1983: 65)

If Africans are to be free in the face of the technological revolution and the Transhumanist revolution in particular, they must enter the techno-scientific dance in a lucid manner. This lucidity can only be maintained by an education that opens up to technoscientific modernity without alienating itself. The education of young Africans today must be able to reconcile mastery of technoscience with mastery of traditions. The battle for Africa's progress (technoprogressism) 
must not be led to the detriment of the bioprotective values found in traditional African societies (bioconservatism). As I wrote in the conclusion of my first essay on the preservation of biodiversity and ethnodiversity, at a time when the African identity is disappearing, with the increasingly pressing threat of Westernization, it is urgent to regain our traditional values which can enable us to mark our presence in the concert of civilizations (Mbessa, 2018: p. 232). Today, not only has westernization accompanied science and technology; but also, it is accompanying Transhumanism.

\section{Conclusion}

At the end of this reflection on the need to reconcile Bioconservatism and Technoprogressism in Africa in order to take up the challenge of progress and especially sustainable development, I can say that opening up to technoscientific culture does not mean abandoning our traditional cultures. Contrary to the revolutionary iconoclasm advocated by Towa or the ethnological conversion advocated by Elungu Pene Elungu, as a cultural pluralist, I stand for a revolution in African mentalities, but one that conserves a place for traditional values that can help us to develop our continent. The village and tradition must become fallow lands of culture, thanks to which the modern African will not become completely acculturated. I am therefore concerned with the preservation of our assets, our values and as Eteki'a Mbumua (1970: p. 75) says, we must refer to the values that constitute our heritage by taking care to retain from our traditional heritage only the solid values that are the seeds of progress. The battle for Africa's progress using the formidable weapon of Western technology must not be a blind battle. Progress is meaningful only when it benefits the man for whom it is sought. With Transhumanism, the humanity of man himself is threatened in the name of that Promethean desire to make us gods, immortal and immune to suffering, disease, pain, sorrow and all other forms of limitation. Yet without these limitations, the earth would no longer be the earth, man would no longer be man and life would no longer be life.

\section{Conflicts of Interest}

The author declares no conflicts of interest regarding the publication of this paper.

\section{References}

Arendt, H. (1972). La crise de la culture (Patrick Guy Gallimard Trad.). Paris: Gallimard.

Binet, J. (1983). La technologie face à la culture de l'Afrique noire. Le mois en Afrique, Revue française d'études politiques africaines, 203-204, 46-65.

Buju, B. (2009). Ecology and Ethical Responsibility from an African Perspective. In M. F. Murove (Ed.), African Ethics: An Anthology of Comparative and Applied Ethics (pp. 281-297). Scottville, MI: University of KwaZulu-Natal Press.

Elungu, P. E. (1987). Tradition africaine et rationalité moderne. Paris: L'Harmattan.

Eteki'a Mbumua, W. A. (1970). Un Certain Humanism. Yaoundé: CLE. 
Ferkiss, V. (1972). L'homme technologique (Pierre Muszlak, Trad.). Tour, Nouveaux Horizons.

Ferry, L. (2016). La révolution transhumaniste, comment la technomédecine et l'ubérisation vont bouleverser nos vies. Paris: Plon.

Gratani, M., Sutton, S. G., Butler, J. R. A., Bohensky, E. L., \& Foale, S. (2016). Indigenous Environmental Values as Human values. Cogent Social Science, 2, 1-17. https://doi.org/10.1080/23311886.2016.1185811

Hamidou Kane, C. (1961). L' aventure ambiguë. Paris: Jullliard.

Jonas, H. (1991). De la gnose au Principe Responsabilité. Un entretien avec Hans Jonas. Paris: Esprit.

Kelbessa, W. (2006). The Rehabilitation of Indigenous Environmental Ethics in Africa. Diogenes, 207, 17-34. https://doi.org/10.1177/0392192105055167

Mbessa, D.-G. (2018). Les Rongeurs de troncs: Plaidoyer pour la préservation de la biodiversité et de l'ethnodiversité. Paris: Jets d'encre.

Mbih Tosam, J. (2019). African Environmental Ethics and Sustainable Development. Open Journal of Philosophy, 9, 172-192. https://doi.org/10.4236/ojpp.2019.92012

Mveng, E. (1980). L'Art et 1 Artisanat africains. Yaoundé.

Njoh-Mouelle, E. (2017). Transhumanism, Science Merchants and the Future of Man (Denis-Ghislain Mbessa, Trad.). Paris: L’Harmattan.

Njoh-Mouelle, E. (2018). What Ethics for Transhumanism: "Enhanced Men" and "Posthumans" Soon in Africa (Denis-Ghislain Mbessa, Trad.). Paris: L'Harmattan.

Otshudi, D. D. (2011). Technoscience et culture africaine contemporaine. In M. Kouam, \& C. Mofor (Eds.), Philosophies et cultures africaines à l'heure de l'interculturalité, Anthologie (Tome 2, pp. 171-185). Paris: L'Harmattan.

Serki, M. A. L. (2006). La culture africaine face aux excès de la technoscience: L'humanisme de Bouba Hama. In P. Hountondji (Ed.), L'ancien et le nouveau: La production du savoir dans l'Afrique d'aujourd'hui (pp. 75-86). Porto Novo: Centre africain des hautes études.

Tangwa, G. B. (1996). Bioethics: An African Perspective. Bioethics, 10, 183-200. https://doi.org/10.1111/j.1467-8519.1996.tb00118.x

Tangwa, G. B. (2010). Elements of African Bioethics in a Western Frame. Bamenda: Langaa Research \& Publishing CIG.

Towa, M. (1971). Essai sur la problématique philosophique dans l'Afrique actuelle. Yaoundé: CLE. 